\title{
Distribution of Eimeria Species and Their Associations in the Farms of the Udmurt Republic
}

\author{
Ekaterina Klimova ${ }^{1}$, Manya Mkrtchyan², Tatyana Babintseva ${ }^{1}$, and \\ Alexandra Reshetnikova ${ }^{1}$ \\ ${ }^{1}$ State Agricultural Academy, Russia \\ ${ }^{2}$ St. Petersburg State Academy of Veterinary Medicine, Russia
}

\section{Abstract}

The purpose of the research was to determine and comparatively analyze the degree of distribution of eimeria species in the northern, central and southern zones of Udmurtia and to identify various associations of these protozoa in farms. The studies of animals of black-motley, Holstein and holsteined black-motley breeds of animals aged 1--16 months, as well as heifers and cows in three zones of the Udmurt Republic showed that eimeriosis is recorded in all experimental farms regardless of the technology

Corresponding Author:

Ekaterina Klimova

laulilitik@yandex.ru

Received: 25 October 2019

Accepted: 15 November 2019

Published: 25 November 2019

Publishing services provided by

Knowledge E

(c) Ekaterina Klimova et al. This article is distributed under the terms of the Creative Commons Attribution License, which permits unrestricted use and redistribution provided that the original author and source are credited.

Selection and Peer-review under the responsibility of the AgroSMART 2019 Conference Committee. of keeping and breed of animals. In order to determine the species of eimeria, the method of oocysts culturing in a thermostat at $25--28{ }^{\circ} \mathrm{C}$ in a $2 \%$ solution of potassium dichromate was used [5]. The results of our studies showed that eight species of bovine eimeria are recorded in animals from the farms of the Udmurt Republic. In the farm located in the central region, the maximum prevalence rate was noted and the clinical signs of eimeriosis are most manifested, up to the death. In our opinion, this is due both to the high prevalence rates, a high percentage of infestation with the most pathogenic species, such as E.zuernii and E. bovis, and mixed infections, the most common of which are the following: E.zuernii + E.bovis; E.zuernii + E.bovis + E.ellipsoidalis; E.zuernii + E.bovis + E.bukidnonensis; E.zuernii + E.bovis +E.subspherica; E.zuernii + E.bovis + E.ellipsoidalis + E.auburnensis; E.zuernii + E.bovis + E.ellipsoidalis + E.auburnensis + E.bukidnonensis + E.subspherica + E.brasiliensis + E.alabamensis.

Keywords: eimeriosis, protozoa, cattle, mixed infection, mono infection.

\section{Introduction}

Among the parasitic diseases of cattle, the most common in recent decades is eimeriosis, which ranks third in terms of economic damage to livestock. The losses from coccidioses in cattle breeding are manifested in the form of a decrease in productivity, an increase in feed consumption by 3 or more times, a decrease in the digestibility of 
Eimeriosis is common in all natural and geographical areas of the world and the Russian Federation, while its prevalence rates can reach up to $100 \%[1,4,9,13,14,16]$. The maximum prevalence rates and the acute cases of the disease are more often recorded in young animals of four to six months of age, with a clinical manifestation mainly in October-November [2, 7].

The source of the causative agent of infestation are adult animals (parasitic carriers). Infection occurs when swallowing eimeriaoocysts with food and water. Transmission factors include oocyst contaminated feeders, drinking bowls, care items. Mechanical vectors - rodents, wild birds and insects are of no small importance in developmental biology. The spread of infection is facilitated by favorable climatic conditions, high humidity in the rooms, an unbalanced diet and a violation of the technology of growing young animals. The prevalence rates in cattle farms known for eimeriosis of the Udmurt Republic reaches $20--80 \%[3,12]$.

At present, the issue of determining not only the genus, but also the species of pathogen remains relevant in the diagnosis of protozooses, since there are significant differences in the biology and pathogenesis of various representatives [8, 11]. Some species of eimeria even at low intensity can have a pronounced pathogenic effect and be accompanied by irreversible disturbances in the animal body, while others even with a high degree of infection do not cause clinical manifestations.

The research purpose was to determine and comparatively analyze the degree of distribution of eimeria species in the northern, central and southern zones of Udmurtia and to identify various associations of these protozoa in farms.

\section{Methods and Materials}

The research material was fecal samples from cattle spontaneously infected with eimeriosis from three regions of the Udmurt Republic located in different zones. Laboratory studies were carried out on the basis of the parasitological laboratory of the department of infectious diseases and pathological anatomy of Izhevsk State Agricultural Academy, in the period 2016--2018. Thus, we examined 5629 samples from cattle of black-motley, Holstein and holsteinized black-motley breeds of animals aged 1--16 months, as well as adult livestock (heifers, cows).

A preliminary diagnosis was made on the basis of epizootological data, clinical signs, and, if possible, the results of a complete parasitological dissection of the organs of the gastrointestinal tract. 
The feces sampling was carried out individually, followed by a study of generally accepted parasitological coprological methods (Darling's method) for the detection of eimeriaoocysts. Samples taken from calves of 2--3 months of age were studied for the presence of exogenous stages of protozoa by the Fulleborn's method that we improved.

Oocysts, taken with a helminthological loop from the surface film, were transferred to test tubes and washed with water by double centrifugation ( $2500 \mathrm{rpm}$ ) to determine the species of eimeria. Then, after draining the supernatant, the sediment was placed in Petri dishes and poured with a thin layer $(0.5 \mathrm{~cm})$ of a $2 \%$ potassium dichromate solution. The solution with collected oocysts was placed in a thermostat and cultured at $25--28^{\circ} \mathrm{C}$. Daily, directly in Petri dishes, oocysts were examined under a microscope $(x 40)$ and determined: the shape, color, nature of the shell structure, length, width of oocysts and spores, the presence or absence of a cap, micropile, polar granule, residual body in the oocyst and spore [5].

\section{Results}

The studies of animals in various zones of the Udmurt Republic showed that eimeriosis is recorded in all experimental farms, regardless of the technology of keeping and breed of animals.

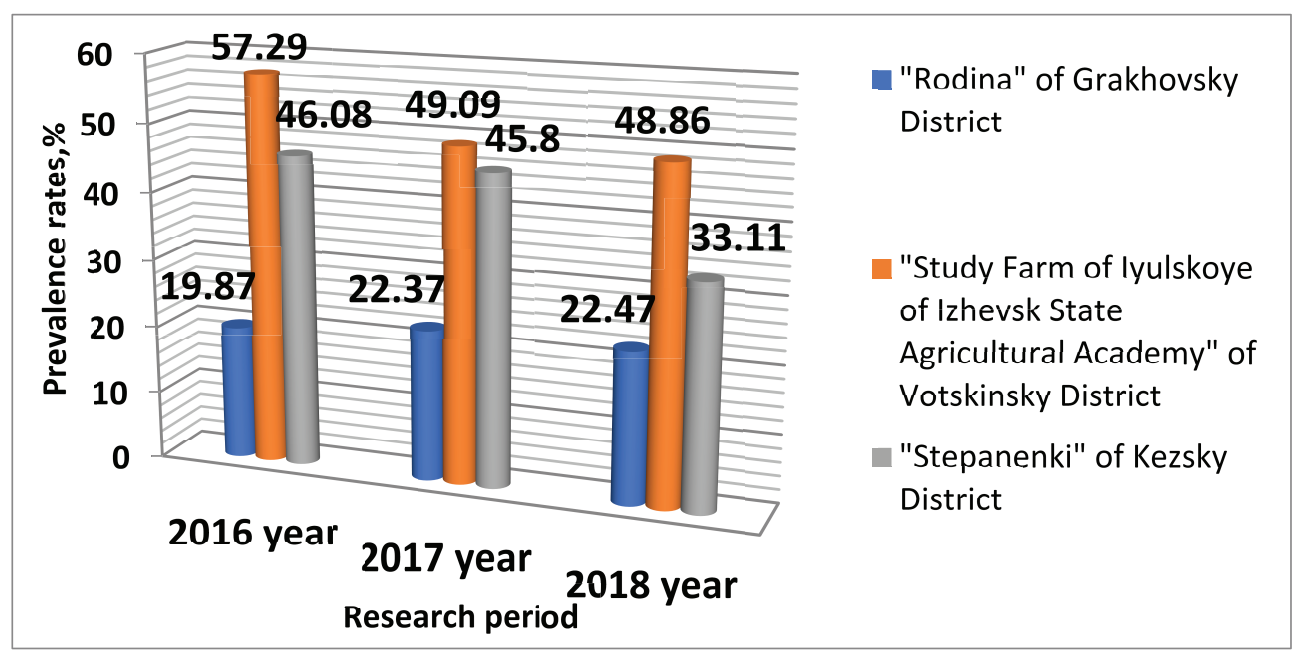

Figure 1: Epizootic manifestation of eimeriosis infection of cattle in farms of the Udmurt Republic.

Analyzing the data presented in Figure 1, it can be concluded that the animals from the farm of Grakhovsky district, which is located in the south of the republic, have a percentage of infection with eimeria stationary 1.5--2 times lower than the farm ("Stepanenki" of the Kezsky district) located in northern Udmurtia. The maximum 
prevalence rates (48.86--57.29\%) are recorded in the central zone --in the "Study Farm of lyulskoye of Izhevsk State Agricultural Academy" of Votskinsky District.

The results of our studies showed that eight species of bovine eimeria parasitize in animals of the indicated farms of the Udmurt Republic.

The percentage ratio of eimeria species in the studied farms is shown in the figures $2--4$.

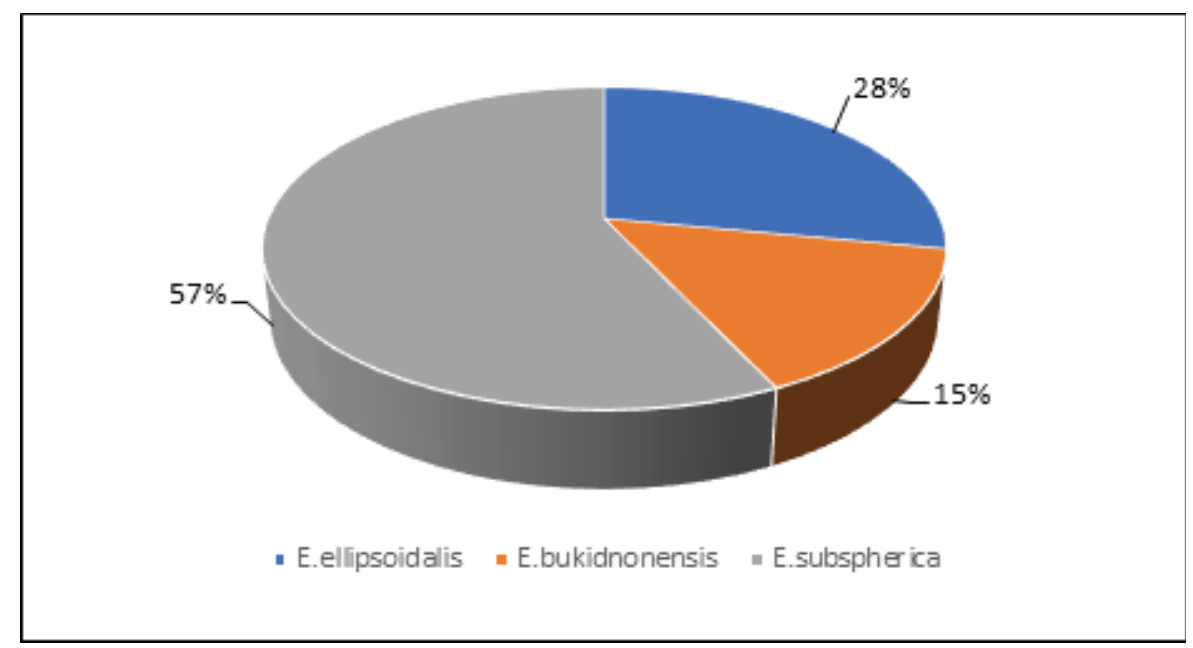

Figure 2: Percentage of species of eimeria in the farm "Rodina" of Grakhovsky District.

As can be seen from the diagram in Figure 2, in the region located in the south of the Udmurt Republic, the minimum number of eimeria ( 3 species), belonging to the least pathogenic, were found. Probably, as a result of this, the clinical manifestation of protozoan diseases in animals was not detected in this farm. In isolated cases, mixed infection of the following species was noted: E.ellipsoidalis + E.bukidnonensis + E.subspherica.

The most diverse picture was recorded in the central part of the republic.

Eight species of eimeria were found in animals of the Votskinsky District, and the clinical signs of eimeriosis, even fatal, were most clearly manifested in this farm, which, in our opinion, is associated with both a high prevalence rates and a high percentage of infection with the most pathogenic species, such as E.zuernii and E.bovis.

At the same time, according to the results of our research, mono-infections were not noted in the "Study Farm of Iyulskoye of Izhevsk State Agricultural Academy", but mixed infections of various combinations of the detected protozoa species were identified, the most common of which are: E.zuernii + E.bovis; E.zuernii + E.bovis + E.ellipsoidalis; E.zuernii + E.bovis + E.bukidnonensis; E.zuernii + E.bovis + E.subspherica; E.zuernii + E.bovis + E.ellipsoidalis + E.auburnensis; E.zuernii+ E.bovis + E.ellipsoidalis + E.auburnensis + E.bukidnonensis + E.subspherica + E.brasiliensis + E.alabamensis 


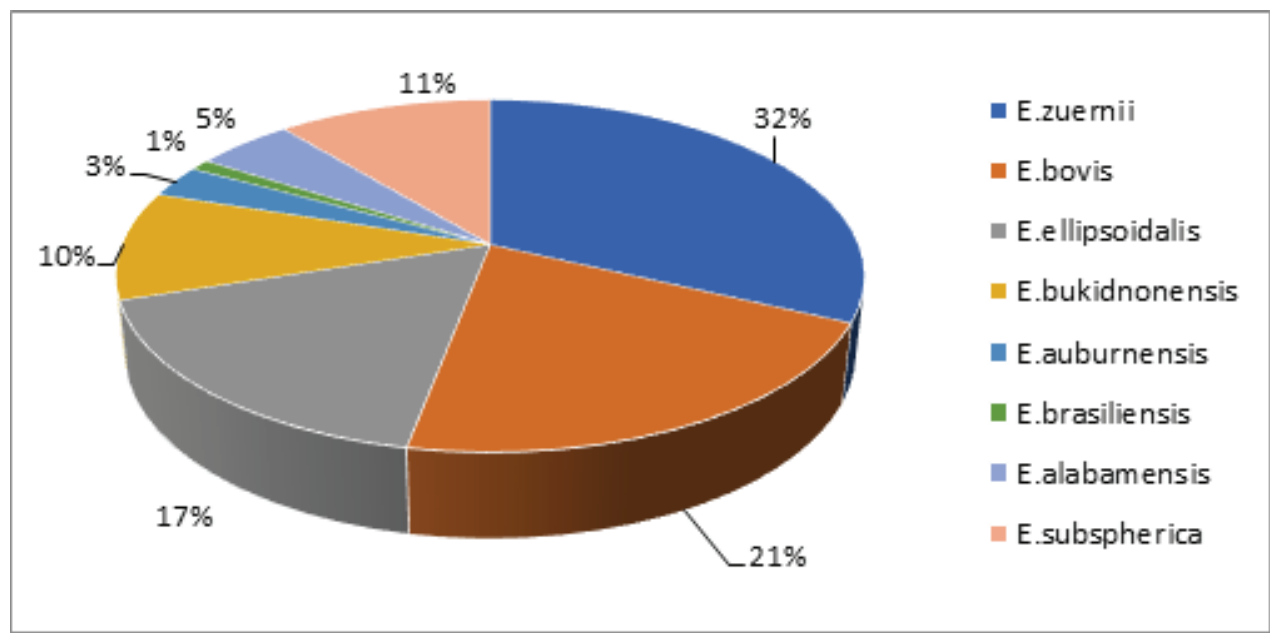

Figure 3: Percentage of eimeria species in animals in the "Study Farm of lyulskoye of Izhevsk State Agricultural Academy" of Votskinsky District.

According to the data presented in Figure 4, in the north of the republic (in the Kezsky District), five species of the causative agent of eimeriosis were found, the dynamics of the percentage ratio of which does not vary significantly (from 17 to $25 \%$ ).

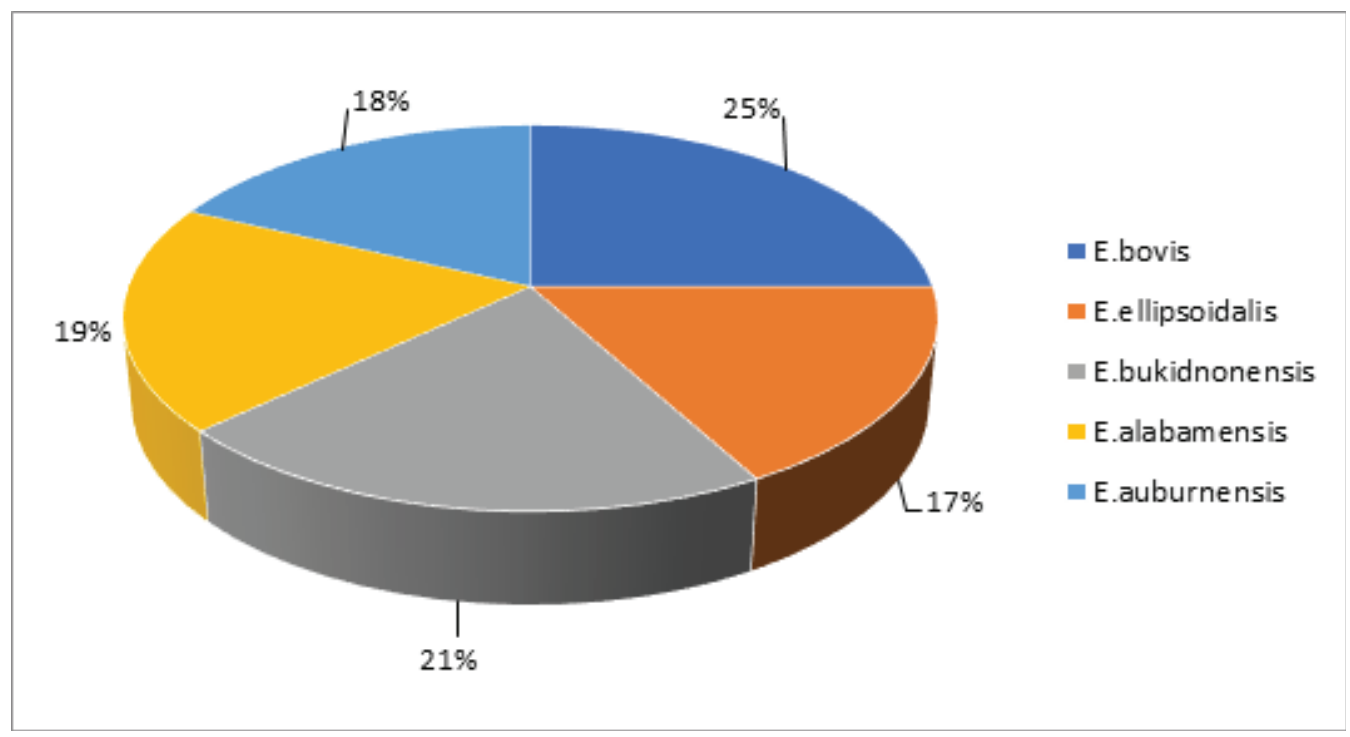

Figure 4: Percentage of eimeria species in the farm "Stepanenki" of Kezsky District.

Most often, two, three, and five-component complexes are detected in animals: E.bovis + E.ellipsoidalis; E.bovis + E.bukidnonensis; E.bovis +E.alabamensis; E.bovis + E.ellipsoidalis + E.bukidnonensis; E.bovis + E.bukidnonensis + E.alabamensis; E.bovis + E.ellipsoidalis + E.bukidnonensis + E.alabamensis + E.auburnensis. With all these mixed infections, the presence of E.bovis is recorded, and it is possible that the clinical manifestation is associated with this, as well as the rather long and severe course of the disease in young animals. 


\section{Conclusion}

Thus, it can be noted that in the studied farms of the Udmurt Republic, from 3 to 8 species of eimeria are registered. The results of our studies showed that most often protozoa occurred in the form of various associations. It is necessary to note that the number of components of parasitocenosis in animals is from two to five and may depend, in particular, on the location of the farm.

\section{Conflict of Interest}

The authors have no conflict of interest to declare.

\section{References}

[1] Andrushko, E.A., Egorov, S.V. (2015). Epizootic monitoring of eimeriosis of young cattle in the farms of Ivanovo and adjacent areas. Rossiyskiyparazitologicheskiyzhurnal, no. 2. Moscow, pp. 27--31.

[2] Ismailov, M. (2012). Age and seasonal dynamics of eimerioticnfection in cattle of the Nakhchivan Autonomous Republic of Azerbaijan. Veterinariya, no. 2. pp. 36--38.

[3] Kalinina, E.S., Mkrtchyan, M.E., Sharafislamova, M.B. (2011). Helminthic-protozoan infections of cattle in farms of the Udmurt Republic. VestnikIzhevskoy SAA, vol. 3(28), pp. 30--33.

[4] Klimova, E.S. (2013). Helminthoses of heifers of random age at Study Farm of Izhevsk State Agricultural Academy. Agrarnayanauka -- innovatsionnomurazvitiyu APK $\vee$ sovremennykhusloviyakh: in Proceedings of All-Russian. Scientific-practical conf. Izhevsk, vol. 3, pp. 27--31.

[5] Krylov, M.V. (1996). Key to parasitic protozoa (human, domestic animals and agricultural plants). St. Petersburg: Zoological Institute RAS, $602 \mathrm{p}$.

[6] Kushnir, Yu.O. (2011). The comparative effectiveness of laboratory methods for the diagnosis of eimeriosis in cattle. Teoriya i praktikabor'by s parazitarnymiboleznyami,no. 12. Moscow,pp.265--267.

[7] Lochkarev, V.A. (2000). Bovine emeriosis. Veterinariya.no. 3, pp. 33--34.

[8] Lutfullin, M.Kh. Latypov, D.G., Cornishina, M.D. (2007). Veterinary helminthology. Kazan: IdelPressPublishing House.

[9] Mironenko, V.M., Yatusevich, A.I. (2000). The problem of eimeriosis in cattle in the Republic of Belarus. Proceedings of International scientific and practical 
conf. "Aktual'nyyeproblemypatologiisel'skokhozyaystvennykhzhivotnykh". Minsk, pp. 390--392.

[10] Mironenko, V.M., Yatusevich, A.I., Subbotina, I.A. (2008). Emeriosis-helminthiase mixed infections of cattle in the Polessky region of Belarus and methods of control. PrirodnayasredaPoles'ya: osobennosti i perspektivyrazvitiya: abstracts of the IV International Scientific Conference. Brest: Al'ternativa, p. 171.

[11] Mironenko, V.M., Korchevskaya, E.A. (2009). Identification of the type of eimeria based on a two-dimensional mathematical analysis of the structure of oocysts. Uchenyyezapiski "Vitebskayaordena "ZnakPocheta" gosudarstvennayaakademiyaveterinarnoymeditsiny". Scientific and practical journal, vol. 45, pp. 123--126.

[12] Mkrtchyan, M.E., Vostrukhina, A.S., Kalinina, E.S. (2012). The current state of the problem of the spread of eimeriosis among farm animals in the Udmurt Republic. Vestniklzhevskoy SAA, vol. 2(31), pp. 49--51.

[13] Usarova, E.I. (2007). Coccidia (Coccidia, Sporozoa) of cattle in the farms of the Republic of Dagestan. Izvestiya DGTTU, no. 1, pp. 58--60.

[14] Duszynski, D.V., Couch, L., Upton, S.J. (2000). The Coccidia of the World. K-State Parasitology Laboratory. Retrieved from: http://www.ksu.edu/parasitology/ world coccidia. Accessed 29 April 2013.

[15] Fitzgerald, P.R., Mansfield, M.E. (1984). Control of bovine coccidiosis with monensin: In nonresistant newborn calves. Am. Journal Veter. Res., vol. 10, pp. 1984--1988.

[16] Jubb, T.F. (1988). Nervous disease associated with coccidiosis in goung cattle farmer and the practitioner. Austral. Veter.Journal, vol. 65. pp. 353--354.

[17] Pellerdy, L.P. (1974). Coccidia and Coccidiosis. D. Budapest: AcademiaiKiado, pp. 13-44 . 